
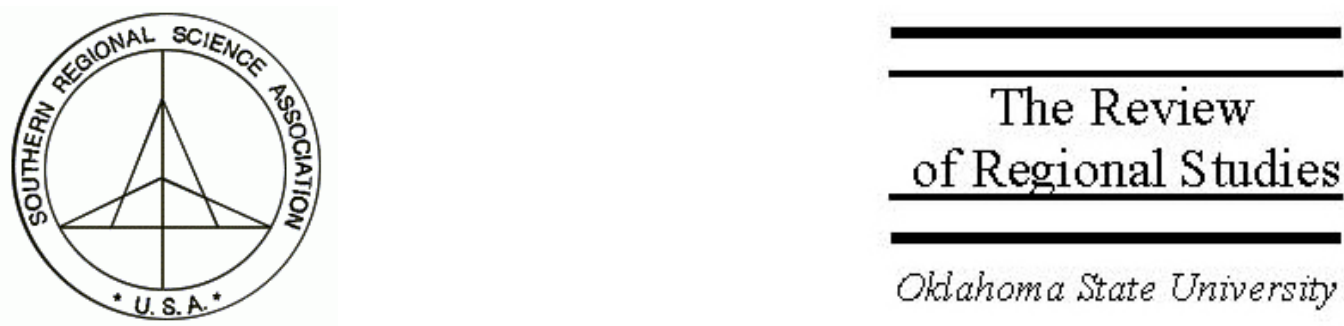

\title{
The Effect of Region, Demographics, and Economic Characteristics on County-Level Voting Patterns in the 2000 Presidential Election
}

\author{
William Levernier \\ School of Economic Development, P.O. Box 8152, Georgia Southern University, \\ Statesboro, GA30460-8152, e-mail: wlevernier@georgiasouthern.edu
}

Anthony G. Barilla

School of Economic Development, P.O. Box 8152, Georgia Southern University, Statesboro, GA 30460-8152, e-mail: barilla@georgiasouthern.edu

\begin{abstract}
This paper seeks to determine how region, demographics, and economic characteristics affected county-level voting patterns in the 2000 U.S. presidential election. The a priori expectation was that the geographic voting patterns that emerged in the election were largely attributable to countylevel differences in demographic and economic characteristics. The results of this study indicate, however, that although economic and demographic characteristics were important determinants of the voting patterns, the regional location of a county was also an important determinant. This suggests that unobserved region-specific cultural characteristics in the United States affected county-level voting behavior in the 2000 presidential election.
\end{abstract}

Keywords: Regional election patterns; Presidential elections; State fixed effects

JEL classification: H30; R10; R20

The authors would like to gratefully acknowledge two anonymous referees and Dan Rickman for their helpful comments. 


\section{INTRODUCTION}

The 2000 presidential election was unique in that it was the closest presidential election in the history of the United States. The election, one of only two presidential elections in which the winner of the popular vote lost the election, ${ }^{1}$ was ultimately decided a month after the election when a ruling by the U.S. Supreme Court halted the manual recount of ballots in Florida. ${ }^{2}$ It was also one of only two presidential elections in which a two-term vice-president seeking to be elected president failed to be elected. ${ }^{3}$

In winning the election, George W. Bush won a plurality of the vote in 30 states, while his opponent, Al Gore, Jr., won a plurality of the vote in 21 states and in the District of Columbia. The states in which Bush received the majority of the vote were primarily in the South, the lower Midwest, and the Mountain West, while the states in which Gore received the majority of the vote were primarily in New England, the upper Midwest, and the Pacific West.

The geographic voting patterns ${ }^{4}$ that emerged in the election raise an important question that is of interest to both political strategists and regional scientists. Namely, were the geographic voting patterns exhibited in the 2000 U.S. presidential election due to unobserved cultural characteristics that are relatively constant within regions but that vary across regions, or were they due to differences in observable demographic and economic characteristics? Much of the commentary that was presented by political observers after the election suggested that differences in region-specific cultural characteristics were the primary cause of the patterns. The purpose of this paper is to investigate the above question and determine the role that each played in influencing the geographic voting patterns. The question is investigated by estimating a series of multivariate regressions that include as explanatory variables a set of variables that capture

\footnotetext{
${ }^{1}$ In only two previous presidential elections, 1824 and 1888, the candidate who won the popular vote failed to be elected president. In the 1824 election, there were four major candidates. Andrew Jackson won the popular vote but no candidate captured a majority of the electoral votes. Since that was the case, the U.S. House of Representatives voted for president. They elected John Q. Adams. In the 1888 election, Grover Cleveland won the popular vote but Benjamin Harrison won 233 of the 401 total electoral votes and was elected president (www.HistoryCentral.com).

${ }^{2}$ On December 8, 2000, the Florida Supreme Court, by a 4-3 vote, orders "manual recounts in all counties with significant numbers of presidential undervotes. Bush appeals the decision to the U.S. Supreme Court and seeks injunctive relief to stop the hand recounts." Undervotes are ballots where the vote tabulation machinery was unable to determine for which candidate the ballot was cast. On December 9, 2000 the U.S. Supreme Court, by a 5-4 vote, halts the manual recounts (CNN 2000).

${ }^{3}$ In the other presidential election lost by a two-term vice-president, Richard M. Nixon lost the 1960 election to John F. Kennedy.

${ }^{4}$ Similar geographic voting patterns were also present in the 2004 presidential election when George W. Bush defeated John Kerry. Only four states switched from voting Republican (Bush) to Democrat (Gore and Kerry) or vice versa from the 2000 election to the 2004 election. Iowa, Louisiana, and New Mexico voted for Gore in 2000 but for Bush in 2004, while New Hampshire voted for Bush in 2000 but Kerry in 2004.
} 
unobserved region-specific cultural characteristics as well as a set of variables that capture observable demographic and economic characteristics.

An important contribution we make to the literature in this paper is that we use counties as the unit of observation. The major advantage of using county-level rather than state-level data to determine the effect that various characteristics had on the geographic voting patterns of the 2000 presidential election is that a model that utilizes county-level data allows for intra-state variation in voting behavior among sub-state geographic units. In states where a majority of the vote was cast for Bush, for example, there were typically some counties where Gore received a majority of the vote. Likewise, in states where a majority of the vote was cast for Gore, there were typically some counties where Bush received a majority of the vote. Within a given state, then, there was often substantial variation in the share of the vote that was cast for a particular candidate in the state's counties. If state-level data were utilized in the investigation, there would be an implicit assumption that these potentially important intra-state variations do not exist. As such, a model estimated from state-level data would likely suffer from omitted variable bias and therefore be less capable of accurately identifying the characteristics that affected geographic voting patterns in the 2000 presidential election than a model estimated from county-level data.

A second important contribution we make to the literature is that we examine a topic that has heretofore been ignored by regional scientists. By merging issues of political science with issues of regional science, we demonstrate that region played an influential role in determining the winner of the 2000 presidential election. If the same finding holds for presidential elections in the post-2000 period, it suggests that region may well play an influential role in determining the political course the United States follows in the coming years.

In the next section, the relevant literature on voting behavior and on the determinants of election outcomes is discussed. There is also a discussion of the literature that examines the role of culture in American politics. In Section 3, the data and the econometric models are derived and discussed. In Section 4, the regression results are discussed, with a particular emphasis on the role of region in explaining the share of the county-level vote received by Al Gore. In Section 5, the state fixed effects obtained in Section 4 are regressed on a set of variables that capture a state's religiosity and geographic location. In the last section, a summary of the paper and concluding remarks are offered.

\section{THE REVIEW OF THE LITERATURE}

Several recent studies have examined the political geography that has emerged in recent elections. Glaeser and Ward (2006, p. 126) argue, "American political parties have increasingly become organized around cultural and religious fissures." Using a timeseries model that predicts the probability that a state will vote for the Republican presidential candidate, where income and church attendance in a state were independent 
variables, they find that prior to the 1980s the two factors were comparable in their explanatory power. Since the 1980s, though, the explanatory power of church attendance relative to income has increased substantially. They further examined the voting behavior of counties since 1864 and found that prior to the 1960s, counties with higher incomes tended to be more Republican; but recently a county's religiosity has become a much stronger predictor of its propensity to vote Republican than its income.

Ansolabehere, Rodden, and Snyder (2006), conversely, argue that while economic and moral issues both influence voters' decisions to vote for one political party instead of another, economic issues are a more important determinant of their voting behavior. Using a probit model that predicts an individual's probability of voting for the Republican presidential candidate, they conclude (p. 112), "the differences in voting behavior between red [Republican] and blue [Democrat] states are largely a function of the distribution of voters' preferences on economic and moral issues.” They also note that Protestants and nonProtestants vary substantially on moral issues and that the moral issues have become an increasingly important determinant of voting behavior over the last 30 years or so. On a related idea, Guiso, Sapienza, and Zingales (2006) propose that one's culture affects both economic and political preferences. They find, for example, that both Protestants and Catholics are more likely to view teaching thrift to one's children as an important value than nonreligious individuals. Regarding political issues, they further find that both Protestants and Catholics view income redistribution more negatively than nonreligious individuals.

Numerous studies in the economic and political science literature have examined the effect of demographics and economic characteristics on election outcomes or on the popularity of a political candidate or politician. In the standard election model, the underlying hypothesis is that voters are more likely to support the candidate representing the incumbent party if economic conditions are favorable and more likely to support the candidate of the opposition party if economic conditions are unfavorable. Much of the economic-based election literature is based on Kramer's (1971) paradigm. The two underlying assumptions of Kramer's paradigm are: 1) in U.S. national elections, the incumbent party is the party of the president; and 2) candidates representing the incumbent party are assumed by voters to be responsible for the economic conditions facing the nation. Based on Kramer's paradigm, candidates representing the incumbent party are expected to do relatively well when the economy is strong and relatively poorly when the economy is weak. Lewis-Beck and Paldam (2000), in a review of the post-1970 literature, report that a common finding is that incumbents are generally re-elected when the economy is strong but defeated when the economy is weak.

The effect of economic conditions on election outcomes or on the popularity of a politician has been examined in previous studies for various political offices. The effect of economic conditions on elections in the United States has been examined for congressional elections (Arcelus and Meltzer 1975; Erikson 1990; Grier and McGarrity 2002; Tufte 1975), for presidential elections or popularity (Balke 1991; Holbrook 1991; Kenski 1977; Markus 1992), for gubernatorial elections (Levernier 1992; Peltzman 1987), and 
for state government elections (Chubb 1988). The effect of economic conditions on elections in other nations has also been examined in several studies (Auberger and Dubois 2005; Cameron and Crosby 2000; Happy 1986; Palmer and Whitten 1999; Pantzalis, Stangeland, and Tuttle 2000). Abrams (1980) finds that voters at the state-level hold incumbent presidents responsible for state-level economic problems. Alvarez and Nagler (1997), in a study of the 1996 U.S. presidential election, find that a voter's support for a candidate is more affected by the voter's perception of economic conditions than by the voter's perception of the candidates' position on various issues.

Many of the studies that examine the effect of economic conditions on election outcomes focus on the effect of real income, but the findings of these studies have been mixed. Erickson $(1990,1988)$ finds no robust evidence that real income affects the midterm elections in the U.S. House. Chappell and Suzuki (1993) assert that real income is an insignificant determinant of U.S. House elections, while Radcliff (1988) finds that the macro-economy has little influence. Tufte (1975), however, finds real income to be a significant determinant of U.S. House elections in mid-term elections. Grier and McGarrity (2002), in an examination of presidential elections, find that real income growth is a barely significant determinant of election outcomes and that the election year "misery index" is insignificant.

While economic conditions can play an important role in determining the outcome of elections, other non-economic factors also are likely to play a role. Some studies have examined the effect of campaign spending on elections outcomes (Gerber 1998) and the effect of federal government spending in a politician's district on election outcomes (Levitt and Snyder 1997). The effect of shirking by a politician on voter support for the politician (Figlio 2000), the effect of "vote-by-mail" elections on the composition of the electorate (Southwell and Burchett 2000), and the effect of various types of voter mobilization drives on voter turnout (Gerber and Green 2000) have also been examined in the literature. Strumpf and Phillipe (1999), in an examination of state-level voting in U.S. presidential elections, find that a state's partisan predisposition is the most important determinant of its voting behavior.

\section{THE DATA AND THE ECONOMETRIC MODEL}

In the previous section, the potential importance of several factors on voting behavior or election outcomes was discussed. The underlying hypothesis of some of the literature that examined the effect of economic conditions on election outcomes was that the candidate representing the incumbent party is likely to receive a larger share of the vote when economic conditions are relatively favorable. Demographic and regional location factors may also influence the share of the vote received by the candidate representing the incumbent party, however, and are considered in this study. Demographic characteristics may affect voting behavior because the policies supported by a political party may have differing impacts on different demographic groups. Members of a demographic group will then tend to support the party whose policies are perceived to be the most favorable. Thus, demographic characteristics of an area's population such as its racial composition, 
age distribution, and family structure may also have affected its support for a particular candidate.

A cursory examination of the voting patterns in the U.S. 2000 presidential election also suggests that regional location strongly affected the share of the vote received by a particular candidate in a given county. A potential reason for the existence of geographic voting patterns is that unobserved cultural characteristics affected voter support for a particular candidate in the 2000 election. Culture is defined as "those customary beliefs and values that ethnic, religious, and social groups transmit fairly unchanged from generation to generation” (Guiso, Sapienza, and Zingales 2006, p. 23). If these cultural characteristics were relatively constant within regions of the U.S. but varied across regions, then geographic voting patterns would have emerged in the election.

This study employs a series of multivariate econometric models where the share of the vote received by $\mathrm{Al}$ Gore in a county in the 2000 presidential election is the dependent variable. It is hypothesized that a county's demographic characteristics, economic characteristics, and unobservable region-specific cultural characteristics all affected Gore's share of the vote. The general form of the model is as follows:

$$
\text { GORE\% }=f(\text { DEMOG }, \text { ECONOMY }, \text { REGION }),
$$

where GORE\% is the percent of the total vote in the county that was cast for Gore, DEMOG is a vector of variables that capture demographic characteristics of the county, ECONOMY is a vector of variables that capture economic characteristics of the county, and REGION is a vector of region-specific variables that apply to the county. Two approaches are employed for REGION: 1) a vector of dummy variables that indicate the Census Division where the county is located (i.e., a division fixed effects model); and 2) state fixed effects. ${ }^{5}$ Six different versions of the model are estimated from observations on 3,113 counties and independent cities. All counties and independent cities in all states except Alaska, along with the District of Columbia, are included as observations. ${ }^{6}$ Each model is estimated using ordinary least squares (OLS). The definition of each explanatory variable is presented in Table 1.

\footnotetext{
${ }^{5}$ Strumpf and Phillipe (1999), in an examination of the six U.S. presidential elections during the 1972-1992 period, find that state fixed effects are an important determinant of the share of a state's vote that is cast for the Democratic candidate. In a study of county-level poverty in the U.S. in 1990, Levernier, Partridge, and Rickman (2000) include state fixed effects as one of the determinants of a county's poverty rate. They note "state fixed effects account for the effects of omitted state variables, which if correlated with the independent variables would otherwise bias the coefficients of the remaining variables by their omission” (p. 478). While county-level voting behavior and county-level poverty rates are different issues, they can be examined using similar models.

${ }^{6}$ The election data and Census Bureau data for Alaska pertain to different jurisdictions. The election data is reported on the basis of 40 election divisions. The Census Bureau data are reported on the basis of 27 boroughs and Census Areas. As such, the demographic and economic characteristics of the election divisions could not be determined from the available data.
} 


\section{TABLE 1}

Variables and their Definitions

\begin{tabular}{|c|c|}
\hline \multicolumn{2}{|l|}{ Region Variables } \\
\hline NEWENG & $\begin{array}{l}\text { A dummy variable that takes a value of } 1 \text { if the county is located in } \\
\text { the New England Census Division, } 0 \text { otherwise. }\end{array}$ \\
\hline MIDATL & $\begin{array}{l}\text { A dummy variable that takes a value of } 1 \text { if the county is located in } \\
\text { the Middle Atlantic Census Division, } 0 \text { otherwise. }\end{array}$ \\
\hline WESTNC & $\begin{array}{l}\text { A dummy variable that takes a value of } 1 \text { if the county is located in } \\
\text { the West North Central Census Division, } 0 \text { otherwise. }\end{array}$ \\
\hline STHATL & $\begin{array}{l}\text { A dummy variable that takes a value of } 1 \text { if the county is located in } \\
\text { the South Atlantic Census Division, } 0 \text { otherwise. }\end{array}$ \\
\hline EASTSC & $\begin{array}{l}\text { A dummy variable that takes a value of } 1 \text { if the county is located in } \\
\text { the East South Central Census Division, } 0 \text { otherwise. }\end{array}$ \\
\hline WESTSC & $\begin{array}{l}\text { A dummy variable that takes a value of } 1 \text { if the county is located in } \\
\text { the West South Central Census Division, } 0 \text { otherwise. }\end{array}$ \\
\hline MOUNTN & $\begin{array}{l}\text { A dummy variable that takes a value of } 1 \text { if the county is located in } \\
\text { the Mountain Census Division, } 0 \text { otherwise. }\end{array}$ \\
\hline PACIFIC & $\begin{array}{l}\text { A dummy variable that takes a value of } 1 \text { if the county is located in } \\
\text { the Pacific Census Division, } 0 \text { otherwise. }\end{array}$ \\
\hline \multicolumn{2}{|l|}{ Demographic Variables } \\
\hline Black Percent & $\begin{array}{l}\text { Percent of the county's population that is black or African-American } \\
\text { alone. }\end{array}$ \\
\hline Rural Percent & Percent of the county's population that resides in a rural area. \\
\hline \% College Graduate & $\begin{array}{l}\text { Percent of the county's } 25 \text {-year-old and older population that } \\
\text { graduated from college. }\end{array}$ \\
\hline$\% 65$ and older & Percent of the county's population that is 65 -years-old and older. \\
\hline \% Female Headed & $\begin{array}{l}\text { Percent of the county's families headed by a female with no husband } \\
\text { present. }\end{array}$ \\
\hline$\%$ Foreign-Born & $\begin{array}{l}\text { Percent of the county's population that is foreign-born and migrated } \\
\text { to the U.S. between } 1995 \text { and } 2000 \text {. }\end{array}$ \\
\hline \multicolumn{2}{|l|}{ Economic Variables } \\
\hline \% Public Assistance & $\begin{array}{l}\text { Percent of the county's household income derived from public } \\
\text { assistance. }\end{array}$ \\
\hline \% Self-Employment & $\begin{array}{l}\text { Percent of the county's household income derived from self- } \\
\text { employment. }\end{array}$ \\
\hline LFPR & The county's civilian labor force participation rate. \\
\hline Male - LFPR & The county's civilian male labor force participation rate. \\
\hline Female - LFPR & The county's civilian female labor force participation rate. \\
\hline \% Goods Employment & $\begin{array}{l}\text { Percent of the county's workers employed in goods-producing } \\
\text { industries (mining, construction, and manufacturing) }\end{array}$ \\
\hline
\end{tabular}


Table 2 shows the number of counties won by Gore and Bush in each Census Division, along with the average share of the county-level vote that Gore received. Gore received a plurality of the vote in 674 counties, while Bush received a plurality of the vote in 2,439 counties. In terms of the proportion of counties won, Gore performed strongest in the New England Division (77.6 percent of the counties won) and the Middle Atlantic Division (39.3 percent of the counties won), while Bush performed strongest in the West North Central Division (88.5 percent of the counties won) and the Mountain Division (86.8 percent of the counties won). Using the average share of the vote to measure strength of performance, Gore also performed strongest in the New England Division and the Middle Atlantic Division (with average shares of 51.6 and 46.0 percent, respectively).

In Table 3, the means and standard deviations of selected variables are reported separately for counties won by Bush and by Gore. There are several notable differences between the two groups of counties. Perhaps most notable is that Gore's average share of the vote in counties where he received a plurality of the vote is substantially smaller than Bush's average share of the vote in counties where he received a plurality of the vote. In the counties Gore won, his average share of the vote was 55.8 percent, while Bush's average share of the vote in the counties he won was 61.4 percent. Another major difference is that the average population is much larger in counties won by Gore than in counties won by Bush. The counties won by Gore had an average population of 197,344, while the counties won by Bush had an average population of only 60,592.

\section{TABLE 2}

Number of Counties Won by Gore, Number of Counties won by Bush, and Average County-Level Share of the Vote won by Gore, by Census Division

\begin{tabular}{lccc}
\hline & $\begin{array}{c}\text { Counties Won } \\
\text { by Gore }\end{array}$ & $\begin{array}{c}\text { Counties Won } \\
\text { by Bush }\end{array}$ & $\begin{array}{c}\text { Average Share of } \\
\text { the Vote for Gore }\end{array}$ \\
\hline West Census Region & 43 & 94 & 41.5 \\
Pacific Div. & 37 & 243 & 31.2 \\
Mountain Div. & 71 & 547 & 35.8 \\
Midwest Census Region & 96 & 341 & 42.4 \\
$\quad$ West North Central Div. & & & 37.5 \\
East North Central Div. & 79 & 391 & 43.1 \\
South Census Region & 94 & 270 & 42.9 \\
West South Central Div. & 143 & 447 & 46.0 \\
East South Central Div. & & & 51.6 \\
South Atlantic Div. & 59 & 91 & \\
Northeast Census Region & 52 & 15 & \\
Middle Atlantic Div. & 674 & 2,439 & \\
New England Div. & & & \\
TOTAL & & & \\
\hline Source: All election data are from Leip, D., Dave Leip’s Atlas of U.S. Presidential Elections, \\
Atlas of the 2000 Presidential Election. Available at www.uselectionatlas.org. \\
\hline
\end{tabular}


Table 3 reveals additional differences between the two groups of counties. Regarding the demographic characteristics, counties where a plurality of the vote was cast for Gore had a proportionally larger black population, a proportionately smaller rural population, a proportionately larger college-educated population, a proportionately smaller share of the population that was 65 years old and older, a larger proportion of female-headed families, and a proportionately larger foreign-born population. Regarding the economic characteristics, counties where a plurality of the vote was cast for Gore had a slightly smaller civilian labor force participation rate (overall and for males), a proportionately smaller workforce employed in goods-producing industries, a larger share of total income accounted for by public assistance income, and a smaller share of total income accounted for by self-employment income.

\section{TABLE 3}

Means and Standard Deviations of Selected Variables

\begin{tabular}{|c|c|c|}
\hline Variable & Counties won by Bush & Counties won by Gore \\
\hline Black Percent & $\begin{array}{c}6.34 \\
(10.36)\end{array}$ & $\begin{array}{c}17.62 \\
(22.17)\end{array}$ \\
\hline Rural Percent & $\begin{array}{c}63.24 \\
(29.32)\end{array}$ & $\begin{array}{c}47.33 \\
(33.46)\end{array}$ \\
\hline \% Public Assistance & $\begin{array}{l}.17 \\
(.15)\end{array}$ & $\begin{array}{l}.26 \\
(.28)\end{array}$ \\
\hline \% Self Employment & $\begin{array}{c}8.01 \\
(3.85)\end{array}$ & $\begin{array}{c}6.17 \\
(2.37)\end{array}$ \\
\hline LFPR & $\begin{array}{l}61.16 \\
(6.66)\end{array}$ & $\begin{array}{l}59.50 \\
(7.96)\end{array}$ \\
\hline Male - LFPR & $\begin{array}{l}67.90 \\
(8.02)\end{array}$ & $\begin{array}{l}65.08 \\
(9.06)\end{array}$ \\
\hline Female - LFPR & $\begin{array}{l}54.86 \\
(6.22)\end{array}$ & $\begin{array}{l}54.45 \\
(7.57)\end{array}$ \\
\hline \% College Graduate & $\begin{array}{l}21.23 \\
(9.35)\end{array}$ & $\begin{array}{c}25.05 \\
(14.95)\end{array}$ \\
\hline$\% 65$ and older & $\begin{array}{l}15.08 \\
(4.23)\end{array}$ & $\begin{array}{l}13.90 \\
(3.50)\end{array}$ \\
\hline \% Female Headed & $\begin{array}{l}13.07 \\
(4.38)\end{array}$ & $\begin{array}{l}19.26 \\
(7.71)\end{array}$ \\
\hline \% Goods Employment & $\begin{array}{l}25.02 \\
(8.93)\end{array}$ & $\begin{array}{l}23.82 \\
(8.45)\end{array}$ \\
\hline \% Foreign-born & $\begin{array}{c}.84 \\
(1.16)\end{array}$ & $\begin{array}{c}1.28 \\
(1.78)\end{array}$ \\
\hline Population & $\begin{array}{c}60,592 \\
(171,017)\end{array}$ & $\begin{array}{c}197,344 \\
(527,408)\end{array}$ \\
\hline Gore Share & $\begin{array}{l}35.42 \\
(8.59)\end{array}$ & $\begin{array}{l}55.83 \\
(7.22)\end{array}$ \\
\hline Bush Share & $\begin{array}{l}61.44 \\
(8.69)\end{array}$ & $\begin{array}{l}40.60 \\
(7.12)\end{array}$ \\
\hline
\end{tabular}


Table 4 reports the expected sign for each explanatory variable. Since the East North Central Census Division is the omitted variable in the division fixed effects models, the expected sign of the coefficient on a particular division dummy variable indicates whether Gore is expected to receive a larger or smaller share of the vote in a county in the division than in a similar county in the East North Central Division. The expected sign was determined by comparing Gore's average share of the county-level vote in the appropriate Census Division to his average share of the county-level vote in the East North Central Division. Therefore, the New England, Middle Atlantic, South Atlantic, and East South Central Census Divisions are expected to have a positive sign. The expected sign of the other four Census Division variables is negative.

The demographic characteristics of a county are also expected to affect its voting behavior. Policies favored by Democrats are generally perceived to be more favorable to blacks, female-headed families, retirees, and foreign-born persons than are policies favored by Republicans. As a result, it is expected that Gore's share of the vote will be larger in counties that have a proportionately large black population, a proportionately large number of female-headed families, a proportionately large population that is 65and older, and a proportionately large foreign-born population, ceteris paribus. Conversely, rural populations are generally considered to be more conservative on political and social issues than urban populations and, as a result, are less likely to support policies favored by Democrats than those favored by Republicans. It is therefore expected that Gore's share of the vote will be smaller in counties that have a proportionately large rural population, ceteris paribus.

Additionally, the economic characteristics of a county are expected to affect its voting behavior. Policies favored by Democrats are generally perceived to be more favorable to people receiving public assistance income and to workers employed in

TABLE 4

Expected Signs of the Regression Coefficients

\begin{tabular}{|c|c|c|c|}
\hline Regional Variables & Expected Sign & Demographic Variables & Expected Sign \\
\hline NEWENG & Positive & Black Percent & Positive \\
\hline MIDATL & Positive & Rural Percent & Negative \\
\hline WESTNC & Negative & \% College Graduate & Ambiguous \\
\hline STHATL & Positive & $\% 65$ and older & Positive \\
\hline EASTSC & Positive & \% Female Headed & Positive \\
\hline WESTSC & Negative & \% Foreign-born & Positive \\
\hline MOUNTN & Negative & & \\
\hline \multirow[t]{7}{*}{ PACIFIC } & Negative & $\underline{\text { Economic Variables }}$ & \\
\hline & & \% Public Assistance & Positive \\
\hline & & \% Self Employment & Negative \\
\hline & & LFPR & Ambiguous \\
\hline & & Male - LFPR & Ambiguous \\
\hline & & Female - LFPR & Ambiguous \\
\hline & & \% Goods Employment & Positive \\
\hline
\end{tabular}


goods-producing industries, which have relatively high rates of unionization. As a result, it is expected that Gore's share of the vote will be larger in counties where a proportionately large share of income is accounted for by public assistance and that have a proportionately large number of workers employed in goods-producing industries, ceteris paribus. Policies favored by Democrats are generally perceived to be less favorable to smallbusiness owners and other self-employed persons than those favored by Republicans. It is therefore expected that Gore's share of the vote will be smaller in counties that have a proportionately large share of their income accounted for by self-employment, ceteris paribus.

The effects of the three labor force participation rate variables and the proportion of the 25 and older population that is college educated are difficult to predict. Republicans are perceived to better promote policies that are favorable to job creation than Democrats. Many persons in the labor force are therefore likely to support Republican policies. Democrats, conversely, are perceived to be more supportive of policies favorable to bluecollar workers, low-skill workers, and labor unions. Many persons in the labor force are likely to support these policies. There is no a priori expectation about which policies have the strongest support from labor force members; hence the expected sign is ambiguous. The proportionate size of a county's college educated population will likely affect its voting behavior because college-educated persons may evaluate a particular candidate's proposed policies differently than a less educated person. There is no a priori expectation whether Democrats or Republicans benefit most from this difference; hence its expected sign is also ambiguous.

\section{THE ECONOMETRIC RESULTS}

The results of six different regression models are reported in Table 5. Model 1 is the most basic regression and includes only eight divisional dummy variables as explanatory variables. (The East North Central division is the omitted category.) Models 2 through 5 are expanded by the addition of the demographic and economic variables. The a priori expectation is that since there is substantial variation in demographic and economic characteristics across counties, the addition of these variables will substantially reduce the effect of the divisional dummy variables on the share of the vote received by Gore. In the final model, state fixed effects replace the Census Division dummy variables.

The results of Model 1 indicate that most of the Census Division dummy variables are statistically significant and have the expected effect. NEWENG and MIDATL have a positive effect on the percent of a county's vote that was cast for Gore, while WESTNC, WESTSC, and MOUNTN have a negative effect. The effect of STHATL, EASTSC, and PACIFIC are all statistically insignificant. The results of the F-statistic further indicate that the division dummy variables are jointly significant.

A common perception is that Gore enjoyed strong support among the AfricanAmerican population but suffered from weak support among the rural population. In Models 2 and 3, variables that account for the percent of a county's population that is 
black and the percent that is rural are separately added to the model. Both variables are found to have the expected effect, with the strength of the black population effect (Model 3 ) being stronger than the rural population effect (Model 2). The inclusion of these variables causes some changes in the effects of the Census Division dummy variables. Specifically, the three variables that were previously found to have an insignificant effect, SOUTHATL, EASTSC, and PACIFIC, now have a statistically significant negative effect in one or both of the regressions. The modified results therefore suggest that Gore's share of the vote in a county in the South Atlantic Census Division, the East South Central Census Division, or the Pacific Census Division was lower than in a similar county in the East North Central Census Division. Thus, by including two demographic variables in the regression equation, the role of region becomes more important in explaining county-level voting patterns in the 2000 presidential election.

In Model 4, the economic and remaining demographic variables are added to the regression equation. The inclusion of these variables induces an additional change in the effect of the Census Division dummy variables. The effect of MIDATL, which was previously positive and statistically significant, is now statistically insignificant.

The regression results in Model 4 also indicate that the demographic variables, except the percent of the county's population that resides in rural areas and the percent of the county's population that is black, all have the expected effect and are statistically significant. The percent of a county's population that is black is statistically insignificant, while the percent of a county's population that is rural has a positive effect (with a large tstatistic). The findings regarding the black and rural populations suggest that Models 2 and 3 suffered from omitted variable bias and overstated the true effects of these characteristics on county-level voting behavior. Model 2 found support for the hypothesis that Gore performed relatively poorly in rural counties, while Model 3 found support for the hypothesis that he performed relatively well in counties with a proportionately large black population, ceteris paribus. When additional variables that capture other relevant demographic and economic characteristics of a county are included in the regression, the hypotheses regarding the negative effect of the rural population and the positive effect of the black populations are no longer supported.

The coefficients of the remaining demographic variables are positive and statistically significant. The results indicate that the percent of a county's vote that was cast for Gore increased as the percent of the county's adult population that graduated from college increased, as the percent of the county's population that was retirement age increased, as the percent of the county's population that was foreign-born and migrated to the United States in the five years prior to the election increased, and as the percent of the county's families that was female-headed increased, ceteris paribus. Collectively, these results suggest that even when a county's regional location is controlled for, the demographic characteristics of the county strongly affected its voting behavior in the 2000 presidential election. 


\section{TABLE 5}

OLS County Election Regressions

\begin{tabular}{|c|c|c|c|c|c|c|}
\hline Variable & Model 1 & Model 2 & Model 3 & Model 4 & Model 5 & $\begin{array}{c}\text { State FE } \\
\text { Model }\end{array}$ \\
\hline \multirow[t]{2}{*}{ NEWENG } & $9.243^{\mathrm{a}}$ & $8.685^{\mathrm{a}}$ & $9.620^{\mathrm{a}}$ & $5.749^{\mathrm{a}}$ & $5.523^{\mathrm{a}}$ & \\
\hline & (6.43) & $(6.23)$ & (7.38) & $(5.11)$ & $(4.94)$ & \\
\hline \multirow[t]{2}{*}{ MIDATL } & $3.604^{\mathrm{a}}$ & $2.415^{\mathrm{a}}$ & $2.684^{\mathrm{a}}$ & -.981 & -.501 & \\
\hline & (3.47) & (2.39) & (2.85) & $(-1.22)$ & $(-0.63)$ & \\
\hline \multirow[t]{2}{*}{ WESTNC } & $-6.609^{a}$ & $-5.272^{\mathrm{a}}$ & $-5.891^{\mathrm{a}}$ & $-1.473^{\mathrm{a}}$ & $-1.690^{\mathrm{a}}$ & \\
\hline & $(-9.64)$ & $(-7.86)$ & $(-9.47)$ & $(-2.50)$ & $(-2.89)$ & \\
\hline \multirow[t]{2}{*}{ STHATL } & .503 & -.741 & -6.343 & -6.860 & -6.137 & \\
\hline & $(0.73)$ & $(-1.11)$ & $(-9.32)$ & $(-11.75)$ & $(-10.42)$ & \\
\hline \multirow[t]{2}{*}{ EASTSC } & .739 & $2.107^{\mathrm{a}}$ & -4.633 & -5.512 & -4.282 & \\
\hline & $(0.95)$ & $(2.77)$ & $(-6.30)$ & $(-8.54)$ & $(-6.44)$ & \\
\hline \multirow[t]{2}{*}{ WESTSC } & $-4.917^{\mathrm{a}}$ & $-4.651^{a}$ & $-7.894^{\mathrm{a}}$ & $-6.829^{a}$ & $-5.657^{a}$ & \\
\hline & $(-6.75)$ & $(-6.59)$ & $(-11.78)$ & $(-11.23)$ & $(-9.01)$ & \\
\hline \multirow[t]{2}{*}{ MOUNTN } & $-11.201^{a}$ & $-10.844^{\mathrm{a}}$ & $-10.315^{a}$ & $-8.509^{a}$ & $-8.104^{a}$ & \\
\hline & $(-13.35)$ & $(-13.33)$ & $(-13.54)$ & $(-12.20)$ & $(-11.66)$ & \\
\hline \multirow[t]{2}{*}{ PACIFIC } & -.874 & $-2.373^{b}$ & -.413 & $-3.197^{\mathrm{a}}$ & $-3.024^{a}$ & \\
\hline & $(-0.81)$ & $(-2.27)$ & $(-0.42)$ & $(-3.58)$ & $(-3.41)$ & \\
\hline \multirow[t]{2}{*}{ Black Percent } & & & $.380^{\mathrm{a}}$ & -.014 & -.028 & $.118^{\mathrm{a}}$ \\
\hline & & & (25.97) & $(-0.61)$ & $(-1.26)$ & $(5.50)$ \\
\hline \multirow[t]{2}{*}{ Rural Percent } & & $-.091^{\mathrm{a}}$ & & .022 & .022 & .022 \\
\hline & & $(-14.26)$ & & (3.01) & (3.07) & (3.48) \\
\hline \multirow[t]{2}{*}{$\%$ College Graduate } & & & & $.209^{\mathrm{a}}$ & $.195^{\mathrm{a}}$ & $.158^{\mathrm{a}}$ \\
\hline & & & & $(9.55)$ & $(8.94)$ & $(8.24)$ \\
\hline \multirow[t]{2}{*}{$\% 65$ and older } & & & & $.324^{\mathrm{a}}$ & $.425^{\mathrm{a}}$ & $.129^{\mathrm{a}}$ \\
\hline & & & & $(6.17)$ & $(7.80)$ & $(2.76)$ \\
\hline \multirow{2}{*}{ \% Female Headed } & & & & $1.142^{\mathrm{a}}$ & $1.137^{\mathrm{a}}$ & $1.021^{\mathrm{a}}$ \\
\hline & & & & (18.03) & $(18.08)$ & $(18.20)$ \\
\hline \multirow[t]{2}{*}{$\%$ Foreign-born } & & & & .842 & $.985^{\mathrm{a}}$ & $.908^{\mathrm{a}}$ \\
\hline & & & & $(6.23)$ & $(7.25)$ & $(7.50)$ \\
\hline \multirow[t]{2}{*}{ \% Public Assistance } & & & & $4.564^{\mathrm{a}}$ & $5.353^{\mathrm{a}}$ & $2.355^{\mathrm{b}}$ \\
\hline & & & & (3.76) & $(4.42)$ & $(2.20)$ \\
\hline \multirow[t]{2}{*}{ \% Self. Employment } & & & & $-.802^{\mathrm{a}}$ & $-.773^{\mathrm{a}}$ & $-.687^{\mathrm{a}}$ \\
\hline & & & & $(-13.22)$ & $(-12.81)$ & $(-12.41)$ \\
\hline \multirow[t]{2}{*}{ LFPR } & & & & $-.150^{\mathrm{a}}$ & & $-.205^{\mathrm{a}}$ \\
\hline & & & & $(-4.19)$ & & $(-6.25)$ \\
\hline \multirow[t]{2}{*}{ Male - LFPR } & & & & & $-.237^{\mathrm{a}}$ & \\
\hline & & & & & $(-8.16)$ & \\
\hline \multirow[t]{2}{*}{ Female - LFPR } & & & & & $.200^{\mathrm{a}}$ & \\
\hline & & & & & $(4.48)$ & \\
\hline \multirow[t]{2}{*}{ \% Goods Employment } & & & & $.101^{\mathrm{a}}$ & $.126^{\mathrm{a}}$ & $.045^{\mathrm{b}}$ \\
\hline & & & & $(4.04)$ & $(5.05)$ & $(1.91)$ \\
\hline R-Square & .141 & .195 & .295 & .518 & .525 & .659 \\
\hline F (all variables) & $63.88^{\mathrm{a}}$ & $83.08^{\mathrm{a}}$ & $144.06^{\mathrm{a}}$ & $184.36^{\mathrm{a}}$ & $179.97^{\mathrm{a}}$ & $99.85^{\mathrm{a}}$ \\
\hline F (states or divisions) & $63.88^{\mathrm{a}}$ & $60.29^{\mathrm{a}}$ & $62.52^{\mathrm{a}}$ & $46.14^{\mathrm{a}}$ & $36.55^{\mathrm{a}}$ & $33.34^{\mathrm{a}}$ \\
\hline $\begin{array}{l}\text { a, b } \text { denote significance } \\
\text { term, the results of whi } \\
\text { rate variables and the } \% \\
\text { for each test is indicate }\end{array}$ & $\begin{array}{l}\text { the } .01 \text { al } \\
\text { are not } \mathrm{r} \\
\text { ollege gr } \\
\text { n Table } 4\end{array}$ & $\begin{array}{l}.05 \text { levels, } \\
\text { rted. All c } \\
\text { late variab }\end{array}$ & $\begin{array}{l}\text { gectively. } \\
\text { icients ex } \\
\text { are tested }\end{array}$ & $\begin{array}{l}\text { he regressi } \\
\text { pt those on } \\
\text { ing a one-t }\end{array}$ & $\begin{array}{l}\text { s were run } \\
\text { le labor for } \\
\text { ed test. Th }\end{array}$ & $\begin{array}{l}\text { h a constan } \\
\text { participatio } \\
\text { xpected sig }\end{array}$ \\
\hline
\end{tabular}


The variables related to the economic characteristics of a county are all found to be statistically significant. The results indicate that the percent of a county's vote that was cast for Gore increased as the percent of the county's total income that was accounted for by public assistance income increased, as the percent of the county's total income accounted for by self-employment income decreased, as the county's labor force participation rate decreased, and as the percent of the county's workers employed in goodsproducing industries increased, ceteris paribus. Like the results of the demographic characteristics, collectively these results suggest that even when a county's regional location is controlled for, the economic characteristics of the county strongly affected its voting behavior.

The result pertaining to goods-producing employment suggests that counties dependent on goods-producing industries were more supportive of Gore than areas less dependent on goods-producing industries. This is not particularly surprising, though, since policies supported by Democrats are generally perceived as being friendlier to blue-collar workers than policies supported by Republicans. The results pertaining to the income variables suggest that people who are relatively dependent on public assistance for at least part of their income tended to favor Gore's anticipated economic policies, while those who received a disproportionate share of their income from self-employment tended to favor Bush's anticipated economic policies. This result is also not surprising, as economic policies supported by Republicans are generally viewed as being more supportive of capitalists and business owners, while economic policies supported by Democrats are generally viewed as being more supportive of wage-earners and the impoverished.

The a priori expected sign on the civilian labor force participation rate was ambiguous. The finding that the sign is negative suggests that voters who were members of the labor force had more faith in Bush's anticipated economic policies than in Gore's. In Model 5, variables that separately account for the male and the female labor force participation rates replace the overall labor force participation rate variable. The results indicate that the male labor force participation rate negatively affected the share of the county's vote cast for Gore while the female labor force participation rate positively affected the share of the county's vote cast for Gore. This suggests that male labor force participants were more likely to favor the Republican's anticipated economic policies while female labor force participants were more likely to favor the Democrat's anticipated economic policies.

The state fixed-effect model includes the same demographic and economic variables as Model 4 but replaces the Census Division fixed effects with state fixed effects. One potential criticism of the division fixed effects approach is that since Census Divisions are relatively large geographic areas, there may be significant cultural differences between various counties in a particular division. If such differences do exist, then counties in a particular Census Division should not be treated as though they are culturally similar. The state fixed effects model avoids this problem by implicitly assuming that counties are culturally similar within a particular state but that they may culturally differ across states. 
The regression results indicate that the state effects are jointly significant, suggesting that when demographic and economic characteristics of a county are controlled for, statelevel cultural characteristics affected the share of the vote that Gore received in a particular county. The effects of the other variables are approximately the same as in Model 4, with a few exceptions. First, the effect of the black population variable is positive (as expected) and statistically significant, suggesting that counties with proportionately large black populations are more supportive of Gore's anticipated policies than are counties with proportionately small black populations. The other differences between the state fixed effects model and Model 4 involve the magnitude of coefficients. The effect of the percent of a county's population that is 65 and older, the percent of a county's total income that is accounted for by public assistance, and the percent of a county's workers that are employed in goods-producing industries all have a much smaller effect on the share of the county's vote cast for Gore in the state fixed effects model than in the Census Division fixed effects models.

The results of Models 4 through 5 and the State Fixed Effects Model indicate that while a county's economic and demographic characteristics affected the share of its vote cast for Gore in the 2000 presidential election, its geographic location also affected how it voted. Since unobserved cultural characteristics of a county are determined largely by its geographic location, the results suggest that unobserved region-specific cultural characteristics of a county affected how it voted. This finding holds for both the division fixed effects models and state fixed effect model, further suggesting that the finding regarding unobserved region-specific cultural characteristics does not depend on how regions are defined.

It should be noted that the results pertaining to the effect of region-specific cultural characteristics must be interpreted somewhat cautiously. If the county-level demographic and economic variables included in the regression models properly controlled for all the demographic and economic characteristics that influenced the county's voting behavior, the fixed effects capture the variation in the percent of the vote cast for Gore that was caused by region-specific cultural characteristics. If, however, relevant demographic and economic characteristics that affect voting behavior are omitted from the models, the fixed effects capture variation that was attributable to not only regional-specific cultural characteristics but to the omitted factors as well. One such omitted factor could be religion, which is the focus of the next section.

\section{THE ROLE OF RELIGION IN DETERMINING STATE FIXED EFFECTS}

A state's religiosity could potentially influence the voting behavior of its inhabitants. It was previously noted that some researchers have found that religion is becoming an increasingly important predictor of voting behavior. The effect of religiosity on the geographic voting patterns in the 2000 presidential election is examined by utilizing the technique employed by Partridge, Partridge, and Rickman (1998) in a study of state-level family income inequality. After estimating several regression equations and finding that income inequality was influenced by state fixed effects, they proceeded to determine the 
impact that several culture-related factors had on the state fixed effects. The factors included in their analysis were the state's religiosity, the state's voting history, and the state's regional location (using Census Regions). To capture a state's religiosity, they used six different variables, each measuring the proportion of the population that held membership in a particular religious denomination. ${ }^{7}$ They found that both religiosity and regional location significantly influenced the value of state fixed effects.

To examine the extent to which religion influences the state fixed effects in this study, the state fixed effects (differenced from the mean) from Table 5 are regressed on a variety of religious and geographic location variables. Four religion categories are included as dependent variables: 1) mainline Protestants, 2) Evangelical Protestants, 3) Catholics, and 4) all other religions. ${ }^{8}$ Each is measured as the number of adherents in the state in the particular religious denomination per 1,000 residents. The omitted group is those not adhering to any religion.

Since the dependent variable for a particular state is the state's fixed effect differenced from the mean fixed effect, and since the dependent variable in the regressions in Table 5 is the percent of a county's vote that was cast for Gore, positive (negative) differences indicate states that cast a relatively large (small) proportion of the vote for Gore, other things equal. Based on the previous discussion, the a priori expectation is that the differenced state effects will be smaller in states that are more religious, especially those that are more Protestant, and in states located in the south, the lower midwest, and the mountain west.

Table 6 reports the regression results for three alternative models. The first model includes as independent variables only the four religion variables. The second model adds three Census Region dummy variables to the religion variables (the Northeast region is the omitted category), and the third model adds eight Census Division dummy variables to the religion variables (the East North Central division is the omitted category). The tstatistics are estimated using the White correction for heteroscedasticity. ${ }^{9}$

\footnotetext{
${ }^{7}$ The six denominations included in their study are mainline Protestant, other Baptist, Catholic, Jewish, Mormon, and other Christian. The omitted category is non-Judaic/Christian.

${ }^{8}$ Mainline Protestant denominations include, but are not limited to, the following: American Baptist in the U.S., Christian (Disciples of Christ), Episcopal, Evangelical Lutheran in America, Friends (Quakers), Presbyterian (U.S.A.), United Church of Christ, and United Methodist Church. Evangelical Protestant denominations include, but are not limited to, the following: Assemblies of God, Christian Churches and Churches of Christ, Church of God (Cleveland, TN), Churches of Christ, Lutheran- Missouri Synod, Mennonite, Seventh-day Adventist, Southern Baptist Convention, and Wesleyan. For more information, see the Association of Religion Data Archives, "U.S. Membership Report," available at www.thearda.com.

${ }^{9}$ The White corrected t-statistics were also utilized by Partridge, Partridge, and Rickman (1998, p. 289). They note corrected t-statistics are appropriate "because the dependent variable consists of estimated state fixed effects, which can introduce heteroskedasticity of an unknown form.”
} 
TABLE 6

State Fixed Effects Regressions

\begin{tabular}{|c|c|c|c|}
\hline Variable & Religion & Religion + Region & Religion + Division \\
\hline \multirow[t]{2}{*}{ Constant } & -2.876 & 4.165 & -2.330 \\
\hline & $(-0.81)$ & (1.17) & $(-0.67)$ \\
\hline \multirow{2}{*}{ Mainline Protestant } & .009 & .001 & .019 \\
\hline & (0.69) & $(0.10)$ & $(1.30)$ \\
\hline \multirow[t]{2}{*}{ Evangelical Protestant } & -.013 & -.011 & -.002 \\
\hline & $(-1.12)$ & $(-1.09)$ & $(-0.17)$ \\
\hline \multirow[t]{2}{*}{ Catholic } & $.025^{\mathrm{a}}$ & .013 & $.018^{\mathrm{a}}$ \\
\hline & (3.08) & $(1.52)$ & (2.99) \\
\hline \multirow[t]{2}{*}{ Other Religions } & $-.022^{\mathrm{a}}$ & $-.021^{\mathrm{a}}$ & -.009 \\
\hline & $(-3.52)$ & $(-3.51)$ & $(-2.00)$ \\
\hline \multirow[t]{2}{*}{ South Region } & & -5.827 & \\
\hline & & $(-1.86)$ & \\
\hline \multirow[t]{2}{*}{ Midwest Region } & & -2.942 & \\
\hline & & $(-1.15)$ & \\
\hline West Region & & $\begin{array}{c}-6.320^{b} \\
(-254)\end{array}$ & \\
\hline East South Central & & & -3.950 \\
\hline Division & & & $(-0.77)$ \\
\hline Mountain Division & & & $\begin{array}{l}-6.634^{a} \\
(-3.44)\end{array}$ \\
\hline West South Central & & & -5.053 \\
\hline \multirow{2}{*}{$\begin{array}{l}\text { Division } \\
\text { Pacific Division }\end{array}$} & & & $(-1.10)$ \\
\hline & & & $\begin{array}{r}1.661 \\
(0.50)\end{array}$ \\
\hline New England Division & & & $\begin{array}{l}4.558^{\mathrm{b}} \\
(2.24)\end{array}$ \\
\hline South Atlantic & & & $-4.426^{b}$ \\
\hline Division & & & $(-2.43)$ \\
\hline Mid Atlantic Division & & & $\begin{array}{c}-2.427 \\
(-1.08)\end{array}$ \\
\hline West North Central & & & -3.782 \\
\hline Division & & & $(-1.23)$ \\
\hline $\mathrm{N}$ & 50 & 50 & 50 \\
\hline R-Square & .454 & .507 & .612 \\
\hline F - statistic & $9.34^{\mathrm{a}}$ & $6.18^{\mathrm{a}}$ & $4.85^{\mathrm{a}}$ \\
\hline \multicolumn{4}{|c|}{$\begin{array}{l}\text { a, b denote significance at the } .01 \text { and } .05 \text { levels, respectively. Mainline Protestant is the number of } \\
\text { adherents in mainline Protestant denominations per } 1,000 \text { residents. Evangelical Protestant is the } \\
\text { number of adherents in Evangelical Protestant denominations per 1,000 residents. Catholic is the } \\
\text { number of adherents in the Catholic Church per } 1,000 \text { residents. Other Religions is the number of } \\
\text { adherents in other religious denominations per } 1,000 \text { residents. Source: The religiosity data were } \\
\text { downloaded from the Association of Religion Data Archives, "Religious Congregations and Member- } \\
\text { ship Study, 2000," available at www.thearda.com. The principal investigator was Association of } \\
\text { Statisticians of American Religious Bodies. }\end{array}$} \\
\hline
\end{tabular}


In the first model, both the number of Catholic adherents per 1,000 residents and the number of other religion (i.e., non-Protestant and non-Catholic) adherents per 1,000 residents are significantly related to state fixed effects (two-tailed test at the .01 level). Further, the F-statistic indicates that the state religiosity variables are jointly related to the state fixed effects. These findings suggest that a state's religiosity plays an influential role in its county-level voting behavior, most likely through its effect on a state's culture. The findings further suggest that the influence of Catholics and of other non-Protestant, nonCatholic religions are the source of the influence.

In the model that contains the Census Region dummy variables, the impact of the religiosity variables is somewhat diminished. The only religion that is statistically significant is other non-Protestant, non-Catholic religions. The results also indicate that the effect of the West dummy variable is negative and significant (at the .05 level), suggesting that relative to the northeast, counties in the west cast a lower proportion of their votes for Gore, ceteris paribus. The group F-statistic indicates that the state fixed effects in Table 5 were influenced by religiosity and regional location, suggesting that state-level cultural characteristics are partly determined by a state's religiosity and by its location.

The third model is identical to the second except that Census Divisions rather than Census Regions define a state's location. The only religious variable that is statistically significant is that pertaining to Catholics (significant at the .01 level), although the variable pertaining to other non-Protestant, non-Catholic religions just misses being significant at the .05 level. The signs are the same as in the first model. Three of the dummy variables are significant at the .05 level. The New England division is found to have a positive influence, while the Mountain division and South Atlantic division are both found to have a negative influence on the state fixed effects. As with the previous model, the group F-statistic indicates that the state fixed effects in Table 5 were influenced by religiosity and regional location, again suggesting that cultural characteristics are influenced by religiosity and by location.

\section{SUMMARY AND CONCLUDING REMARKS}

This paper has sought to determine the effect that region, demographics, and economic characteristics played in county-level voting patterns in the 2000 U.S. presidential election. The 2000 presidential election was selected as the focus of this study because of its historical uniqueness in being the closest presidential election in the history of the United States and being the only one since 1888 in which the winner of the popular vote lost the election. There were distinct regional voting patterns in the election, where the states won by Gore were primarily in the upper Midwest, New England, and the Pacific West and where the states won by Bush were primarily in the South, the lower Midwest, and the Mountain West. The a priori expectation was that the voting patterns were caused by county-level differences in demographic and economic characteristics and would largely disappear after controlling for the differences. 
A series of OLS regressions was estimated to test the underlying theories. The effect of unobserved region-specific cultural characteristics on county-level voting patterns was incorporated into the regression models using two approaches. The first approach utilized models that included Census Division dummy variables as explanatory variables, while the second approach utilized a state fixed effects model.

A major contribution we make to the literature in this paper is that the econometric models use counties rather than states as the unit of observation. This approach should be appealing to regional scientists because it allows for a more accurate assessment of the role of region in determining voting behavior. Since substantial variation in voting behavior often exists within states, county-level data allows for the existence of these variations when estimating the effect that a particular demographic or economic characteristic has on voting patterns.

We find that the regional location of counties as well as county-level demographic and economic characteristics affected the voting patterns that emerged in the 2000 U.S. presidential election. The role of region was found to be influential in both the Census Division fixed effects models and state fixed effects models, indicating that region affected the voting patterns regardless of how the regions were defined. This relatively important finding suggests that unobservable, region-specific cultural characteristics influenced the voting behavior of counties. As such, they likely played a major role in the outcome of the 2000 presidential election. If these characteristics are relatively constant over time, it further suggests that they will likely play a significant role in the outcome of future presidential elections as well.

\section{REFERENCES}

Abrams, B.A., 1980. "The Influence of State-Level Economic Conditions,” Public Choice 35(5), 623-631.

Alvarez, R.M. and J. Nagler, 1997. "Economics, Entitlements and Social Issues: Voter Choice in the 1996 Presidential Election," Division of Humanities and Social Sciences, California Institute of Technology, Social Science Working Paper 1021: Pasadena, CA.

Ansolabehere, S., J. Rodden, and J.M. Snyder, Jr., 2006. “Purple America,” Journal of Economic Perspectives 20(2), 97-118.

Arcelus, F. and A.H. Meltzer, 1975. "The Effect of Aggregate Economic Variables on Congressional Elections,” American Political Science Review 69(4), 1232-1239.

Association of Religion Data Archives, 2000. "Religious Congregations and Membership Study," Available at www.thearda.com.

Auberger, A. and E. Dubois, 2005. "The Influence of Local and National Economic Conditions on French Legislative Elections,” Public Choice 125(3-4), 363-383.

Balke, N.S., 1991. "Partianship Theory, Macroeconomic Outcomes, and Endogenous Elections,” Southern Economic Journal 57(4), 920-935.

Cameron, L. and M. Crosby, 2000. "It's the Economy Stupid: Macroeconomics and Federal Elections in Australia,” The Economic Record 76(235), 354-364. 
Chappell, H.W. and M. Suzuki, 1993. "Aggregate Vote Functions for the U.S. Presidency, Senate, and House,” Journal of Politics 55(1), 207-217.

Chubb, J.E., 1988. "Institutions, the Economy, and the Dynamics of State Elections," American Political Science Review 82(1), 133-154.

CNN, 2000. "How We Got Here: A Timeline of the Florida Recount," www.cnn.com/ 2000/ALLPOLITICS/stories/12/13/got.here/index.html.

Erikson, R.S., 1988. “The Puzzle of the Midterm Loss,” Journal of Politics 50(4), 10111029.

1990. "Economic Conditions and the Congressional Vote: A Review of the Macrolevel Evidence,” American Journal of Political Science 34(2), 373-399.

Figlio, D.N., 2000. "Political Shirking, Opponent Quality, and Electoral Support,” Public Choice 103(3-4), 271-284.

Gerber, A., 1998. "Estimating the Effect of Campaign Spending on Senate Election Outcomes using Instrumental Variables,” American Journal of Political Science 92(2), 401-411.

Gerber, A. and D.P. Green, 2000. "The Effects of Canvassing, Telephone Calls, and Direct Mail on Voter Turnout: A Field Experiment," American Political Science Review 94(3), 653-663.

Glaeser, E.L. and B.A. Ward, 2006. "Myths and Realities of American Political Geography,” Journal of Economic Perspectives 20(2), 119-144.

Grier, K.B. and J.P. McGarrity, 2002. "Presidential Party, Incumbency, and the Effects of Economic Fluctuations on House Elections, 1916-1996,” Public Choice 110(1-2), 143-162.

Guiso, L., P. Sapienza, and L. Zingales, 2006. "Does Culture Affect Economic Outcomes?” Journal of Economic Perspectives 20(2), 23-48.

Happy, J.R., 1986. "Voter Sensitivity to Economic Conditions: A Canadian-American Comparison,” Comparative Politics 19(1), 45-56.

HistoryCentral.com, 2007. "United States Presidential Elections," Available at www. historycentral.com/elections/index.html.

Holbrook, T.N., 1991. "Presidential Elections in Space and Time," American Journal of Political Science 35(1), 91-109.

Kenski, H.C., 1977. "The Impact of Economic Conditions on Presidential Popularity,” Journal of Politics 39(3), 764-773.

Kramer, G.H., 1971. "Short-Term Fluctuations in U.S. Voting Behavior, 1896-1964,” American Political Science Review 65(1), 131-143.

Leip, D., 2000. Dave Leip's Atlas of U.S. Presidential Elections, Atlas of the 2000 Presidential Election, available at www.uselectionatlas.org.

Levernier, W., 1992. "The Effect of Relative Economic Performance on the Outcome of Gubernatorial Elections,” Public Choice 74(2), 181-190.

Levernier, W., M.D. Partridge, and D.S. Rickman, 2000. "The Causes of Regional Variations in U.S. Poverty: A Cross-County Analysis,” Journal of Regional Science 40(3), 473-497.

Levitt, S.D. and J.M. Snyder, Jr., 1997. "The Impact of Federal Spending on House Election Outcomes,” Journal of Political Economy 105(1), 30-53. 
Lewis-Beck, M.S. and M. Paldam, 2000. “Economic Voting: An Introduction,” Electoral Studies 19(2-3), 113-121.

Markus, G.B., 1992. "The Impact of Personal and National Economic Conditions on Presidential Voting,” American Journal of Political Science 36(3), 829-834.

Palmer, H.D. and G.D. Whitten, 1999. "The Electoral Impact of Unexpected Inflation and Economic Growth,” British Journal of Political Science 29(4), 623-639.

Pantzalis, C., D.A. Strangeland, and H.J. Tuttle, 2000. "Political Elections and the Resolution of Uncertainty: The International Evidence," Journal of Banking and Finance 24(10), 1575-1604.

Partridge, J.S., M.D. Partridge, and D.S. Rickman, 1998. "State Patterns in Family Income Inequality,” Contemporary Economic Policy 16(3), 277-294.

Peltzman, S., 1987. "Economic Conditions and Gubernatorial Elections," American Economic Review 7(2), 293-297.

Radcliff, B., 1988. "Solving a Puzzle: Aggregate Analysis and Economic Voting Revisited,” Journal of Politics 50(2), 413-434.

Southwell, P. and J. Burchett, 2000. "Does Changing the Rules Change the Players? The Effect of All-Mail Elections on the Composition of the Electorate," Social Science Quarterly 81(3), 837-845.

Strumph, K.S. and J.R. Phillippe, Jr., 1999. "Estimating Presidential Elections: The Importance of State Fixed Effects and the Role of National Versus Local Information," Economics and Politics 11(1), 33-50.

Tufte, E.R., 1975. "Determinants of the Outcomes of Midterm Congressional Elections," American Political Science Review 69(3), 812-826.

U.S. Department of Commerce, Bureau of the Census, 2000. Census of the Population. Summary File 3. Available at www.census.gov. 